\title{
GCMS Determination of Organochlorine Pesticides (OCPs) in Fish from River Cauvery and Veeranam Lake
}

\author{
R. BHUVANESHWARI AND R. BABU RAJENDRAN \\ Department of Environmental Biotechnology, School of Environmental Sciences \\ Bharathidasan University, Tiruchirappalli-620024, Tamil Nadu, India
}

Received 26 November 2011; Accepted 18 January 2012

\begin{abstract}
Organochlorine Pesticides (OCPs) were analyzed using Gas Chromatography-Mass Spectrometer (Selective Ion Monitoring mode) in the muscle tissues of five fish species such as $O$. mossambicus, L. parsia, E. suretensis, C. striata and $S$. wynaadensis from seven locations of River Cauvery and one location in Veeranam Lake. OCPs viz., DDTs, HCHs, CHLs, cyclodienes, heptachlor, HCB and mirex were detected with varying concentrations among species and locations. Mirex which was not reported in the fish tissues elsewhere reported in this study. The study on the risk associated with the consumption of fish species that had higher concentrations of aldrin, dieldrin and mirex showed significant carcinogenic risk to the human beings.
\end{abstract}

Keywords : Cyclodienes, Mirex, L. parsia, S. wynaadensis, Carcinogenic risk.

\section{Introduction}

Organochlorine pesticides are of great concern due to their occurrence at high concentrations in aquatic ecosystems, despite bans on production and usage ${ }^{1}$. Many of the organochlorine compounds are substances that have high toxicity. They accumulate in organisms and biomagnified through the food chain, so consumption of fish from contaminated areas may be a real health risk for the consumers ${ }^{2}$. Most of these compounds are considered to act as environmental hormones, which disrupt reproductive cycles of wildlife and believed to be possible carcinogens or mutagens ${ }^{3}$. In India, the residues of chlorinated pesticides have been detected in almost all the segments of environment due to their extensive use in the past, which have shown potential to biomagnify/accumulate in animal tissue, human blood, adipose tissue and breast milk.. Considerable research has been carried out in India related to OCPs in the fish Studies ${ }^{4-8}$. This investigation focuses on analyzing the concentration of chlorinated pesticides viz. HCH isomers, DDTs, heptachlor, aldrin, dieldrin, endrin, mirex, $\mathrm{HCB}$, chlordanes in water, sediment and biota in River Cauvery and Lake Veeranam using Gas Chromatography-Mass Spectrometer (GC-MS) and carcinogenic risk associated with consumption of fish from the polluted site to the local population. 


\section{Materials and Methods}

\section{Sample Collection}

Samples were collected at various locations in River Cauvery and in Veeranam Lake. The sampling in River Cauvery includes seven dams viz., Hogennakkal, Mettur, Jatarpalayam, Mayanur, Mukumbu, Kallanai and Anaikarai and Nathamalai from Veeranam Lake. Fish samples such as Etroplus suratensis (E.s), Oreochromis mossambicus (O.m), Liza parsia (L.p), Channa striatus (C.s) and Silurus wynaadensis (S.w) were obtained directly from the fisherman at sampling sites. All the samples were transported to the laboratory using ice boxes. The fish samples were deep frozen at $-18^{\circ} \mathrm{C}$ until analysis, in order to prevent decomposition. The fish samples were dissected out and $2 \mathrm{~g}$ of muscle tissue was taken for the analysis of organochlorine pesticides.

\section{Extraction of OCPs in biota}

Two grams of well homogenized fish muscle tissue was ground with $5 \mathrm{~g}$ of activated sodium sulfate until a fine powder was obtained and extracted twice with $50 \mathrm{ml}$ of acetone and the extract was filtered into a conical flask. The filtered extract was extracted with $350 \mathrm{ml}$ of deionised water, $15 \mathrm{~g}$ of $\mathrm{NaCl}$ and $40 \mathrm{ml}$ of $\mathrm{n}$-hexane/ethyl acetate $(3: 2)$ in a separating funnel. The organic layer was collected and sample was again reextracted with $40 \mathrm{ml}$ of $\mathrm{n}-$ hexane/ethylacetate (3:2) and organic layer was collected. The combined extract was then passed through anhydrous sodium sulfate, then concentrated to a few $\mathrm{ml}$ again and $20 \mathrm{ml}$ of $\mathrm{n}$-hexane was added to the extract and condensed to $1 \mathrm{ml}$ in rotary evaporator and then purified using florosil. The packed column was prerinsed with $18 \mathrm{ml}$ of $\mathrm{n}$-hexane. The elution was subsequently carried out using $13 \mathrm{ml}$ of $\mathrm{n}$-Hexane. The extract was further condensed to $1 \mathrm{ml}$ for GCMS analysis.

\section{Instrumentation \& $Q A Q C$}

The samples were analysed in GCMS (Gas Chromatograph- Mass Spectrophotometer) (QP 2010 Shimadzu Corp, Japan) equipped with capillary column DB-1 (30m long, ID 0.32mm) and 5\% methyl phenyl silicone. The limit of detection (LOD) of OCPs was determined three times of the standard deviation of the blank. Before analysis, standards were run to check for the column performance, peak height and resolution. From stock solution of organochlorine pesticides standard containing cocktail of 17 pesticides hexachlorocyclohexane $(\alpha, \beta \& \gamma$ $\mathrm{HCH}$ ), Cyclodiene (aldrin, dieldrin and endrin), heptachlor, hexachlorobenzene (HCB), trans-Chlordane, cis-Chlordane, mirex and diphenyl aliphatic (p,p'-DDE, o,p'-DDE, o,p'DDD, p,p'-DDD, o,p'-DDT, p,p'-DDT), $200 \mathrm{ppb}(200 \mathrm{ng} / \mathrm{ml})$ of working standard was prepared.For the standard calibration, eight different concentrations from $5 \mathrm{ng} / \mathrm{ml}$ to $200 \mathrm{ng} / \mathrm{ml}$ were prepared. All standards show a linear range from $5 \mathrm{ppb}$ to $200 \mathrm{ppb}$. The coefficient $\left(\mathrm{R}^{2}\right)$ values ranged from 0.9746 to 0.9985 for 8 concentrations levels. The limit of detection (LOD) as $3 \mathrm{~S}$ varied from 0.69 to $18.23 \mathrm{ng} / \mathrm{ml}(3 \mathrm{~S})$ for OCPs. The chromatogram of pesticide standards was represented in Fig-1. 


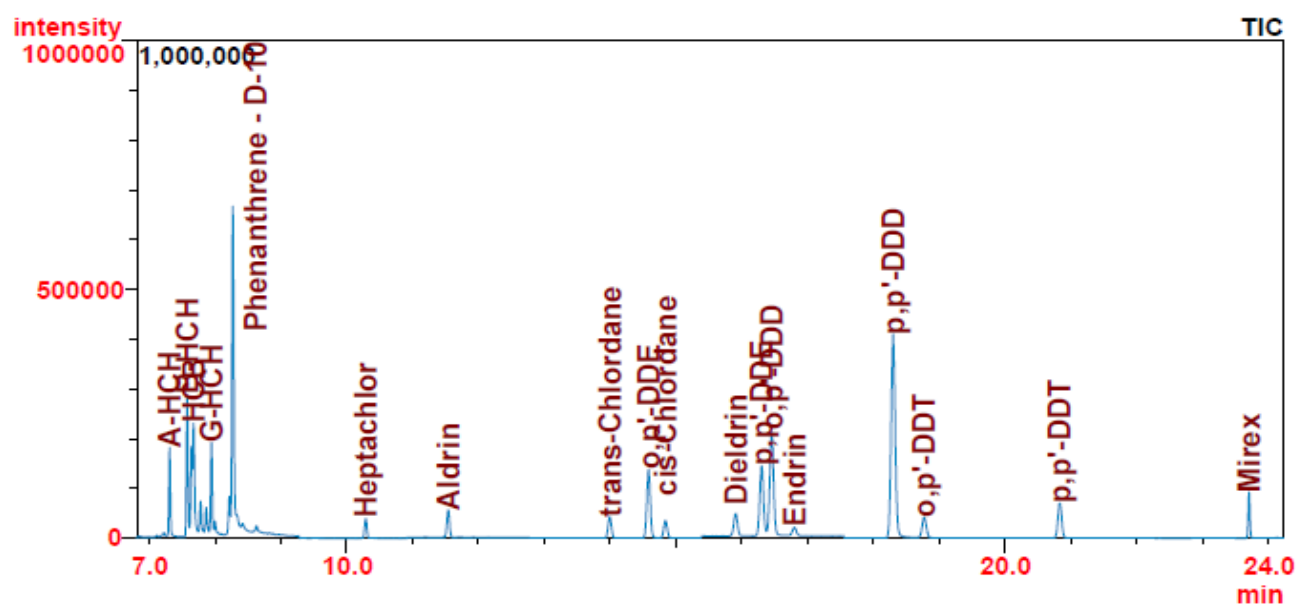

Figure 1. Chromatogram of Pesticide standards.

\section{Result and Discussion}

The mean concentrations of pesticides in five representative species from seven different locations of River Cauvery were represented in Fig-3. The highest concentration of Total $\mathrm{HCH}(228 \mathrm{ng} / \mathrm{g})$ was observed in L. parsia from Hogennakal. Also, Mayanur $(23.6 \mathrm{ng} / \mathrm{g}$ ) and Kallanai (33.1 ng/g) showed higher levels of $\Sigma-\mathrm{HCH}$ in L. parsia but in Veeranam Lake the maximum concentration was observed in E. suretensis $(3.5 \mathrm{ng} / \mathrm{g})$ (Table 1). The mean concentration of HCHs was found to be $86 \mathrm{ng} / \mathrm{g}$ in O.mossambicus in River Cauvery which was much higher than the earlier report ${ }^{9}$ in the same species collected from Ciliwung River, Bogor, Indonesia $(6 \mathrm{ng} / \mathrm{g})$. The maximum concentration of $\mathrm{\Sigma HCH}$ in $O$. mossambicus observed in this study was $33.2 \mathrm{ng} / \mathrm{g}$ found to be 8 fold greater than the highest concentration $(4.2 \mathrm{ng} / \mathrm{g})^{10}$ in the muscle tissue of $O$. niloticus in Lake Burullus, Egyptian Mediterranean Sea. $\Sigma \mathrm{HCH}$ at a concentration of $118 \mathrm{ng} / \mathrm{g}$ in E. suretensis in River Cauvery ${ }^{7}$ was reported which was higher than the present study $(40.85 \mathrm{ng} / \mathrm{g})$. The HCHs in the $C$. striata $(35.2 \mathrm{ng} / \mathrm{g})$ was greater than the murrel C. marulius from the various streams of River Cauvery, India $(0.14 \mathrm{ng} / \mathrm{g})^{8}$. Among the isomers of the $\mathrm{HCH}, \alpha$ and $\beta$-isomers were the most widely detected. The predominance of $\alpha$ and $\beta$-isomers of $\mathrm{HCH}$ in the fish samples of Meric delta (Turkey) ${ }^{11}$ was observed. The wide distribution of $\alpha-\mathrm{HCH}$ isomer in the fish samples may be explained as the $\gamma-\mathrm{HCH}$ can be easily degraded by microorganisms in soil and bottom sediments and photochemically isomerized to $\alpha$-isomer, whereas $\beta$-isomer is highly persistent in the environment ${ }^{12}$.

Table 1. Concentration of OCPs (ng/g wet wt.) in the fish samples from Veeranam Lake.

\begin{tabular}{ccccccc}
\hline Species & $\boldsymbol{\Sigma}$-HCH & HCB & Aldrin & Dieldrin & Chordane & $\Sigma$-DDT \\
\hline $\boldsymbol{O} . \boldsymbol{m}$ & 1.21 & - & - & 0.5 & 0.37 & - \\
$\boldsymbol{L} . \boldsymbol{p}$ & 1.82 & - & 1.7 & 57 & - & 3.23 \\
$\boldsymbol{E} . \boldsymbol{s}$ & 3.5 & - & - & 16 & - & 3.3 \\
$\boldsymbol{C . s}$ & 0.82 & - & - & - & - & - \\
$\boldsymbol{S} . \boldsymbol{w}$ & - & 1.2 & - & - & - & 0.03 \\
\hline
\end{tabular}

-: Not detected; $\sum \mathrm{HCH}$ - Sum of $\alpha, \beta$ and $\mathrm{HCH}$ isomers; $\sum$ DDT - Sum of $\mathrm{o,p}$ 'and p,p'- DDE,DDD,DDT. 
Elevated concentration of HCB was found in L. parsia at Hogennakal (35. $3 \mathrm{ng} / \mathrm{g}$ ). $\mathrm{HCB}$ concentration $(0.26 \mathrm{ng} / \mathrm{g})$ found in the tilapia O. mossambicus from Ciliwung River, Bogor, Indonesia ${ }^{9}$ and from rivers in India $(<0.03 \mathrm{ng} / \mathrm{g})^{13}$ were low compared to the average level in the present study $(11.4 \mathrm{ng} / \mathrm{g})$ in the same species. But the concentration was considerably lower than the recommended tolerance limit of $200 \mathrm{ng} / \mathrm{g}$ proposed by EU MRLs of OC tolerance in food of animal origin expressed on fat weight ${ }^{14}$. Significantly higher concentration of heptachlor (ND- $21.8 \mathrm{ng} / \mathrm{g}$ ) was recorded in the C. striata in the river Cauvery compared to C. punctatus $\left(\mathrm{BDL}-0.52 \mathrm{ng} / \mathrm{g}\right.$ ) collected from river Gomti ${ }^{8}$. The highest concentration of heptachlor was detected in S. wynaadensis at Kallanai.

Among cyclodienes aldrin was detected in almost all species in all locations. Dominance of aldrin over the dieldrin in fish samples was reported ${ }^{8,15,16}$. The highest concentration was quantified at Jatarpalayam (128 ng/g) and Mukumbu (87.5 ng/g) in $L$. parsia. Also in Veeranam Lake aldrin was observed only in L. parsia (Table 1). Higher mean concentration of $41 \mathrm{ng} / \mathrm{g}$ aldrin in the cat fish collected from some river in the Edo state, Nigeria ${ }^{17}$ was reported than the present study in the cat fish $S$. wynaadensis $(33 \mathrm{ng} / \mathrm{g})$. The average levels of aldrin and endrin in the $C$. striata were 6.66 and $226 \mathrm{ng} / \mathrm{g}$ in the river Cauvery $^{8}$, respectively which was higher than the level in C. punctatus $(2.2$ and $0.14 \mathrm{ng} / \mathrm{g})$ from Gomti river. Significantly higher concentration of dieldrin $(57 \mathrm{ng} / \mathrm{g})$ from Veeranam Lake (Table 1) was observed in C. striata than the dieldrin in C. punctatus $(1.12 \mathrm{ng} / \mathrm{g})$ from Gomti river $^{8}$. The respective maximum residual limit for dieldrin/aldrin and endrin proposed by European Union were 200 and $50 \mathrm{ng} / \mathrm{g}$ of food of animal origin expressed on fat weight. Except $O$. mossambicus from Jatarpalayam concentration in fish species from all other locations do not exceeded the MRL of EU (1998). Higher concentrations of aldrin and dieldrin in the sediment pose risks to the sediment dwellers that are preyed on by birds and fish.

Among chlordane the detection frequency of trans-chlordane was higher than the cisChloradane. trans-Chlordane (TC) is generally more susceptible to degradation than cis- Chloradane (CC), a TC/CC ratio $>1$ may indicate fresh use of chlordane ${ }^{18}$. The highest concentration of $\Sigma$-chlordane $(13.7 \mathrm{ng} / \mathrm{g})$ was observed in L. parsia at Hogennakal. $0.65 \mathrm{ng} / \mathrm{g}$ of chlordane was noticed in $O$. mossambicus from river Cauvery which was very low compared to the concentration $(7.2 \mathrm{ng} / \mathrm{g})^{9}$ in the Ciliwung River, Bogor, Indonesia. The European Union MRL for chlordane was $50 \mathrm{ng} / \mathrm{g}$. None of the fish species both from river Cauvery and Veeranam Lake exceeded the limit. Highest concentration of Mirex was detected in $S$. wynaadensis at three out of seven locations Hogennakal (157 ng/g), Jatarpalayam (190 ng/g) and Mukumbu $(67 \mathrm{ng} / \mathrm{g})$ in river Cauvery.

DDT and its metabolites undergo strong biomagnifications along trophic transfer. Metabolism of DDT in fish is generally accomplished through dechlorination to DDE but generally not to $\mathrm{DDD}^{18}$. Therefore the presence of DDD in fish tissue can be from direct input as DDD from the environment. Concentrations of DDTs in fish tissues were ranged from ND - 1.8, ND - 65, ND - 4.4, ND - 2.24 and ND - $2805 \mathrm{ng} / \mathrm{g}$ in O. mossambicus, $L$ .parsia, E. suretensis, C. striata and S. wynaadensis respectively. Slightly higher concentration of p,p'-DDT $\left(0.77 \mathrm{ng} / \mathrm{g}\right.$ and p,p'-DDE $(3.28 \mathrm{ng} / \mathrm{g})^{7}$ in E. suratensis whereas in the present study the concentration was 0.02 and $0.69 \mathrm{ng} / \mathrm{g}$ respectively in the same species. Elevated levels of p,p'-DDE (31 ng/g), p,p'-DDD (14.6 ng/g) and p,p'-DDT (11.9 ng/g) in the C.striata from Songkhla lake, Thailand ${ }^{19}$ was reported than the present study where the mean concentration was found to be $0.8 \mathrm{ng} / \mathrm{g}$ of p,p'-DDE, $0.79 \mathrm{ng} / \mathrm{g}$ of p,p'-DDD and 11.9 $\mathrm{ng} / \mathrm{g}$ of p,p'-DDT in the river Cauvery. The concentration of DDTs $(1.9 \mathrm{ng} / \mathrm{g})$ in $O$. mossambicus in the present study was much lower than the earlier reports in the same species $18 \mathrm{ng} / \mathrm{g}$ from rivers of South $\operatorname{India}^{13}$ and in tilapia $O$. mossambicus $(1100 \mathrm{ng} / \mathrm{g})$ from Ciliwung River, Bogor, Indonesia ${ }^{9}$. In the present study the range of p,p'-DDE was ND - 
$8.14 \mathrm{ng} / \mathrm{g}$ in the mullet L. parsia which was comparable to p,p'-DDE (ND - $3.81 \mathrm{ng} / \mathrm{g}$ ) in the muscle tissue of mullet L. aurata from Lake Ganzirri and Straits of Messina (Sicily, Italy $)^{20}$. The European Union Maximum Residual Limit of $\Sigma$ DDT in the animal food is $1000 \mathrm{ng} / \mathrm{g}$. Only S. wynaadensis (2805 ng/g) from Jatarpalayam (Fig-2) of river Cauvery has exceeded the limit. Fig-3 shows the higher concentration of cyclodiene compounds in all the species. S. wynnadensis has exhibited the maximum concentration of three out of seven OCPs viz mirex, DDTs and Heptachlor. Likewise L. parsia also has shown higher concentrations for three OCPs such as $\mathrm{HCHs}, \mathrm{HCB}$ and chlordane. C. straita has demonstrated greater accumulation of cyclodiene compounds. The result of the present study is similar to the report ${ }^{20}$ that indicated the usage of mullet L. aurata as pollution bioindicator. Both in River Cauvery and Veeranam Lake the concentration of cyclodiene compounds were high.

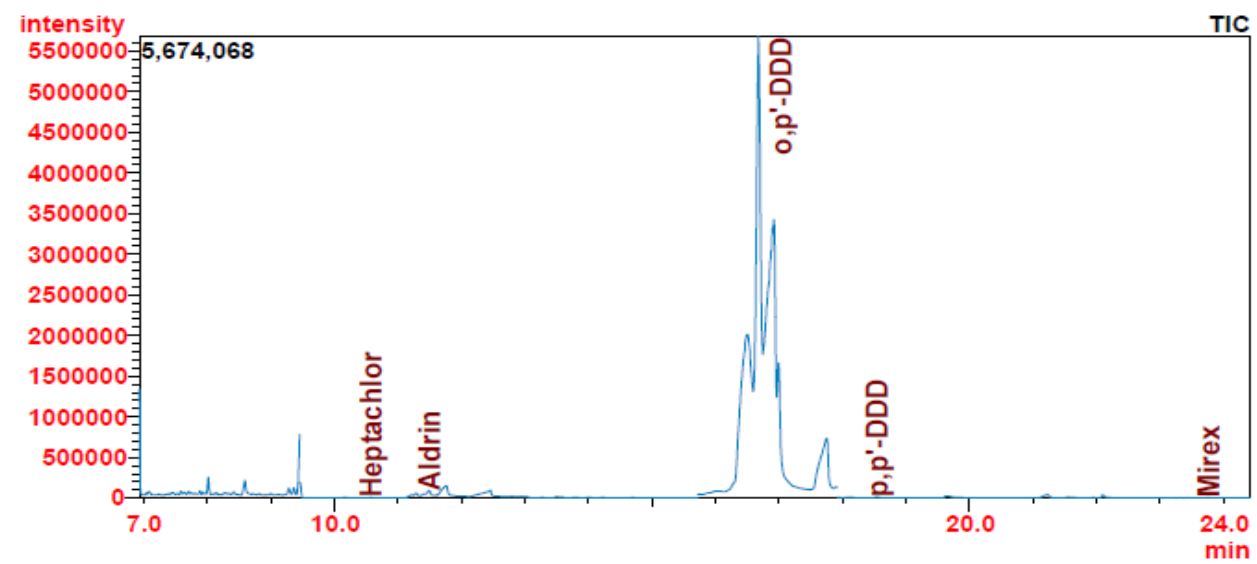

Figure 2. Chromatogram of OCPs in S. wynaadensis Jatarpalayam from River Cauvery.

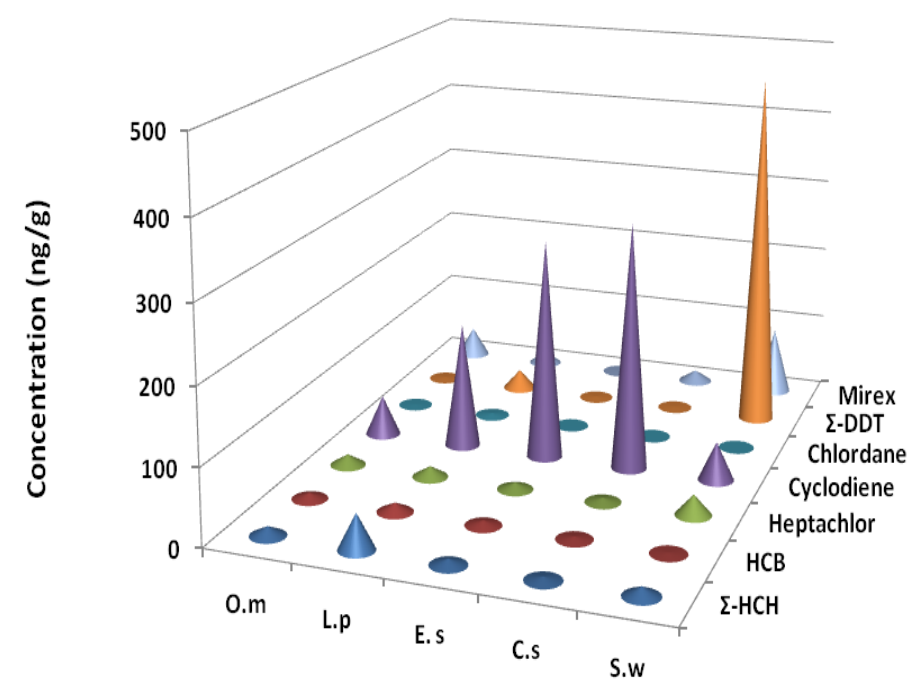

Figure 3. Mean concentration of OCPs in fish species from River Cauvery. 


\section{Carcinogenic risk due to OCPs in fish}

Assessment of risk to human health has been carried out worldwide to examine the potential health risk due to exposure to toxic contaminants in various environmental media and foodstuff $^{21}$. Food consumption databases have been established to provide the necessary information for assessing the health risks associated with consumption of contaminated food in countries such as the U.S ${ }^{22}$. An assessment of the cancer risks to human health due to consumption of fish containing organochlorine contaminants was undertaken and the results were given in the Table 2. To provide more accurate assessment of the risks, it is necessary to establish specific food consumption of the Indian population so that the health risks to the target population can be meaningfully assessed, and the risks can be effectively managed. The average daily consumption of fish in India is $12 \mathrm{~g} /$ day $^{23}$. Organochlorine pesticides have been regularly monitored in the food stuff in various countries to evaluate their potential health risk to humans ${ }^{21,24}$. In the present investigation the carcinogenic risk to human population was made for five fish species contaminated with OCs that has been regularly consumed viz., O. mossambicus, L. parsia, E. suratensis, C. striata, S. wynnadensis collected from River Cauvery and Veeranam Lake. Except $\gamma-\mathrm{HCH}$ and chlordane the mean concentrations of all other OCPs in all the fish species might result in carcinogenic risk. Among the OCPs, aldrin and mirex lead to carcinogenic risk. Aldrin has been classified as possible human carcinogen ${ }^{25}$ and mirex is a suspected human carcinogen. The concentration of aldrin in L. parsia was the highest which may able to cause cancer in 1.3 in every ten thousand people and Mirex in S. wynnadensis instigate cancer in 6 out of ten thousand people. HCB $\left(3.3 \times 10^{-6}\right)$ in L. parsia, Heptachlor $\left(2 \times 10^{-5}\right)$, dieldrin $\left(4.2 \times 10^{-5}\right)$ and DDT $\left(2.8 \times 10^{-5}\right)$ in $S$. wynnadensis have shown greater than unity out of one million, the intake of these fish species may cause lifetime cancer risk. The mean concentration of chlordane in fish sample had lesser carcinogenic effect (Table 2).

Table 2. Carcinogenic Risk (CR) of OCPs through fish from River Cauvery.

\begin{tabular}{lccccc}
\hline \multirow{2}{*}{ OCPs } & $\boldsymbol{5}$ O.m & $\boldsymbol{L} . \boldsymbol{p}$ & $\boldsymbol{E} . \boldsymbol{s}$ & $\boldsymbol{C} . \boldsymbol{s}$ & $\boldsymbol{S} . \boldsymbol{w}$ \\
\cline { 2 - 6 } $\boldsymbol{\alpha}$-HCH & $8.6 \times 10^{-6}$ & $4.7 \times 10^{-6}$ & $3 \times 10^{-6}$ & $3.8 \times 10^{-7}$ & $1.9 \times 10^{-6}$ \\
$\boldsymbol{\gamma}$-HCH & $7.7 \times 10^{-7}$ & $7.5 \times 10^{-7}$ & $2.3 \times 10^{-7}$ & $2.6 \times 10^{-8}$ & $4 \times 10^{-7}$ \\
HCB & $2.6 \times 10^{-6}$ & $3.3 \times 10^{-6}$ & $1.2 \times 10^{-6}$ & $9.6 \times 10^{-7}$ & $5.1 \times 10^{-7}$ \\
Heptachlor & $1.1 \times 10^{-5}$ & $1.4 \times 10^{-5}$ & $5.6 \times 10^{-6}$ & $3.7 \times 10^{-6}$ & $2 \times 10^{-5}$ \\
Aldrin & $1 \times 10^{-4}$ & $1.31 \times 10^{-4}$ & $3 \times 10^{-5}$ & $2.3 \times 10^{-5}$ & $1.1 \times 10^{-4}$ \\
Dieldrin & $6.4 \times 10^{-6}$ & $2.2 \times 10^{-5}$ & $6.4 \times 10^{-6}$ & $3.7 \times 10^{-6}$ & $4.2 \times 10^{-5}$ \\
Chlordane & $4.4 \times 10^{-8}$ & $1.4 \times 10^{-7}$ & $4.2 \times 10^{-9}$ & $1.8 \times 10^{-9}$ & $3.9 \times 10^{-9}$ \\
DDT & $8.6 \times 10^{-8}$ & $1.3 \times 10^{-6}$ & $5.8 \times 10^{-7}$ & $4.5 \times 10^{-8}$ & $2.8 \times 10^{-5}$ \\
Mirex & $2.5 \times 10^{-4}$ & $8.3 \times 10^{-5}$ & $4.2 \times 10^{-6}$ & $1 \times 10^{-4}$ & $5.5 \times 10^{-4}$ \\
\hline
\end{tabular}

The risk was also calculated for fish samples from Veeranam Lake. The highest carcinogenic activity of pesticides such as $\alpha-\mathrm{HCH}\left(2.27 \times 10^{-6}\right)$, HCB $\left(3.3 \times 10^{-6}\right)$, Aldrin $\left(5.78 \times 10^{-6}\right)$ and Dieldrin $\left(2 \times 10^{-4}\right)$ was found in L. parsia. Carcinogenic risk of $\alpha-\mathrm{HCH}(3.2$ $\mathrm{x} 10^{-6}$ ) in mullet from Thailand ${ }^{26}$ which was closer to the carcinogenic activity of $\alpha-\mathrm{HCH}$ in the mullet, L. parsia in Veeranam Lake of this study. The carcinogenic risk for aldrin and mirex were ranged from $2 \times 10^{-5}$ to $1.4 \times 10^{-4}$ and $4.2 \times 10^{-6}$ to $5.5 \times 10^{-4}$, respectively. This 
means that there is a strong possibility of 2 to 6 persons in one million of the population may acquire cancer when such a concentration of OCPs are to be consumed at the estimated rate. $S$. wynnadensis and L. parsia are most the preferred fish by the local population and higher levels of pesticides in these species are serious concern.

\section{Conclusion}

Invariably all the species studied has higher concentration of cyclodienes while concentrations of other pesticides varied. The present investigation on the carcinogenic risk assessment of OCPs through the consumption of contaminated fish may pose carcinogenic risk to the local population. Indeed the main reason for OC contamination can be related to the still widely and illegal use of OC pesticides in agriculture in India. Monitoring of pesticides should be performed over a period of time and with a frequency that allows all seasonal events to be taken in to consideration. With sufficient continued monitoring and by adopting the combinations of policies such as restrictions in the usage and alterations in some of the agricultural management practices will bring a solution towards pesticide loading into aquatic systems.

\section{Acknowledgement}

Authors are thankful to United Nations University, Japan and Shimadzu Corporation, Japan for the GC-MS facility sponsored through the project "Environmental Governance and Monitoring of POPs in the Asian Coastal Hydrosphere". Also thank the university authorities for the facilities provided to carryout this research.

\section{References}

1. Guruge K S and Tanabe S. Mar. Pollut. Bull. 2001, 42(3), 179 -186.

2. Bayarri S, Baldassarri L T, Iacovella N, Ferrara F and Di Domenico A. Chemosphere. 2001, 43, $601-610$.

3. Colborn T, Vom Saal F S and Soto A M. Environ. Health. Perspect, 1993, 101, 378 - 384.

4. Amaraneni S R. Environ. Int. 2006, 32, 294 - 302.

5. Sankar T V, Zynudeen A A, Anandan R and Nair P G V. Chemosphere. 2006, 65, 583 590.

6. Kaur M, Sharma J K, Gill J P, Bedi J S and Joia B S. Bull. Environ. Contam. Toxicol. 2008, $154-157$.

7. Abida B, Hariharan S and Khan I. Int.J. ChemTech. Res. 2009, 1, 237 - 244.

8. Malik A, Singh K P and Ojha P. Bull. Environ. Contam. Toxicol. 2007, 78, 335 - 340.

9. Sudaryanto M, In M, Kajiwara N, Takahashi S, Hartono P, Muawanah O, Omori K, Takeoka H and Tanabe S. Environ. Inter. 2007,33, 750 - 758.

10. Said T O, El Moselhy K M, Rashad A M and Shredah M A. Bull. Environ. Contam. Toxicol. 2008, 81, $136-146$.

11. Erkmen B and Kolankaya D. Int. J. Environ. Anal. Chem. 2006, 86, 161 -169.

12. Malaiyandi M and Shah S M. J. Environ. Sci. Health A. 1984, 19, 887 - 910.

13. Senthilkumar K, Kannan K, Subramanian A and Tanabe S.Environ. Sci. Pollut. Res, 2001, 8(1), 35 - 47.

14. Ayas A, Barlas N E and Kolankaya D. Aquat. Toxicol. 1997, 39, 171 - 181.

15. Barlas N E. Bull. Environ. Contam. Toxicol. 1997, 62, $278-285$.

16. Iyamu I, Asia O K and Egwakhide P A. Int. J. Phy. Sci. 2007, 2 (9), 237 - 241.

17. Qiu Y W, Zhang G, Liu G Q, Guo L L, Li D and Wai, O W H. Estuarine, Coastal and Shelf Science. 2009, 83, $60-66$.

18. Schmitt C J, May, T W and Cowman D F.Rev. Environ. Contam. Toxicol. 1999, 162, 43 -104 . 
19. Kumblad L, Olsson A, Kounty V and Berg H. Environ. Pollut. 2001, 112, 193 - 200.

20. Licata P, Bella, G D, Dugo G, and Naccari F. Chemosphere. 2003, 52, 231 - 238.

21. NRC. National Research Council, National Academy Press, Washington, DC, USA. 1993.

22. Dougherty C P, Holtz S H, Reinert J C, Panyacosit L, Axelrad D A and Woodruff T J. Environ. Res. 2000, 84, 170 - 185.

23. FAO. Food and Agriculture Organization of the United Nations, Rome, Italy. 2001.

24. MacIntosh D L, Spengler J D, Ozkaynak H, Tsai L and Ryan P B. Environ. Health. Persp. 1996, 104, $202-209$.

25. US EPA. Environmental Protection Agency, Washington, DC, EPA/600/R-06/096F. 2008.

26. Samoh A N H, Alikahir T, Nawawi L and Kumaraih T. Malayasia. J. Che. 2009, 11, 14 -18 . 


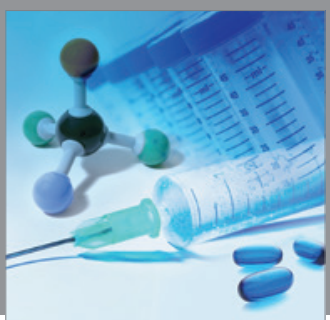

International Journal of

Medicinal Chemistry

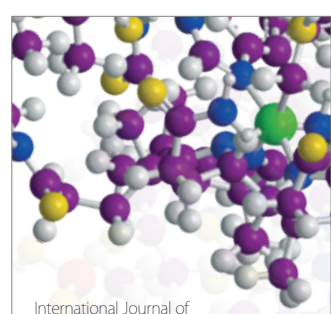

Carbohydrate Chemistry

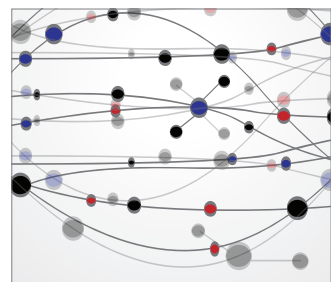

The Scientific World Journal
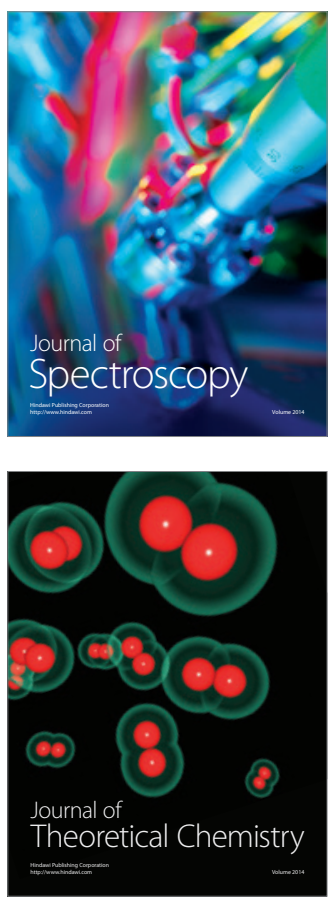
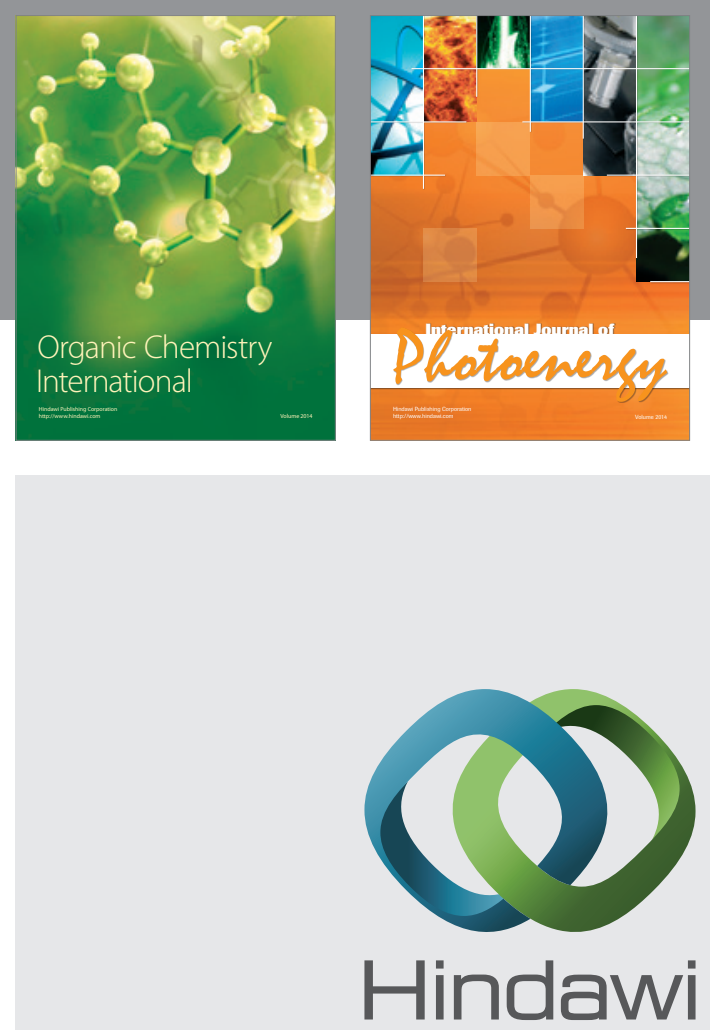

Submit your manuscripts at

http://www.hindawi.com
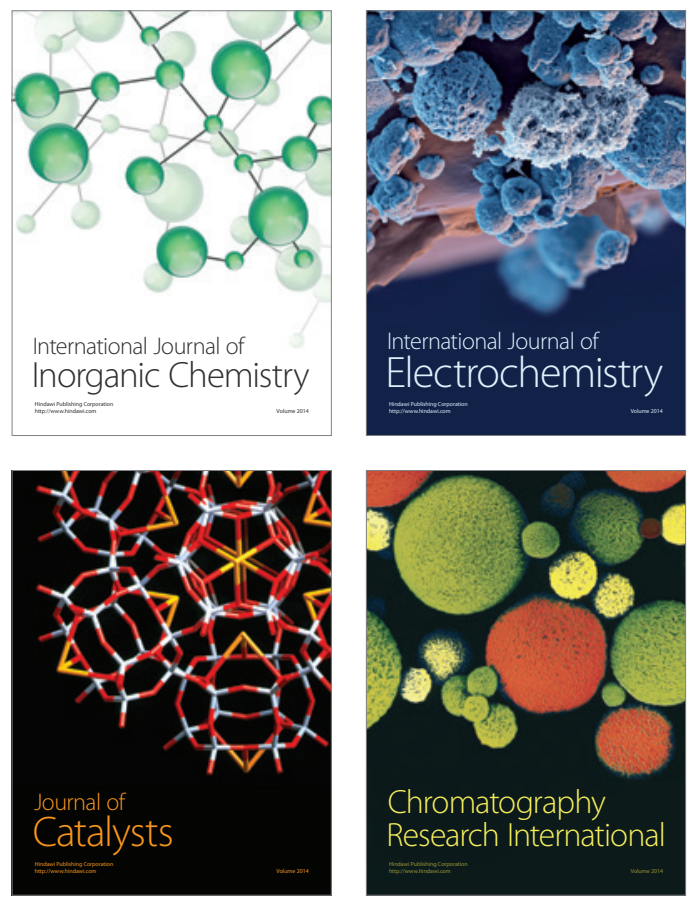
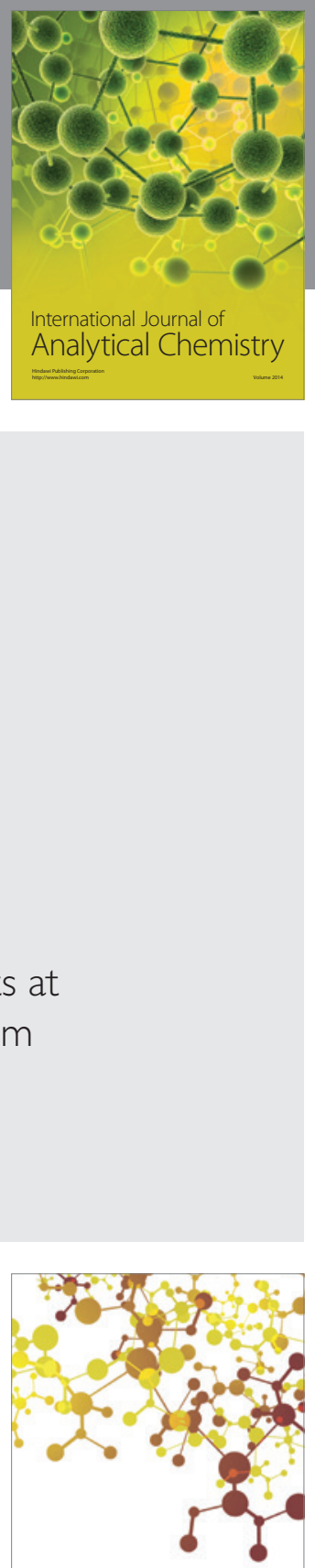

Journal of

Applied Chemistry
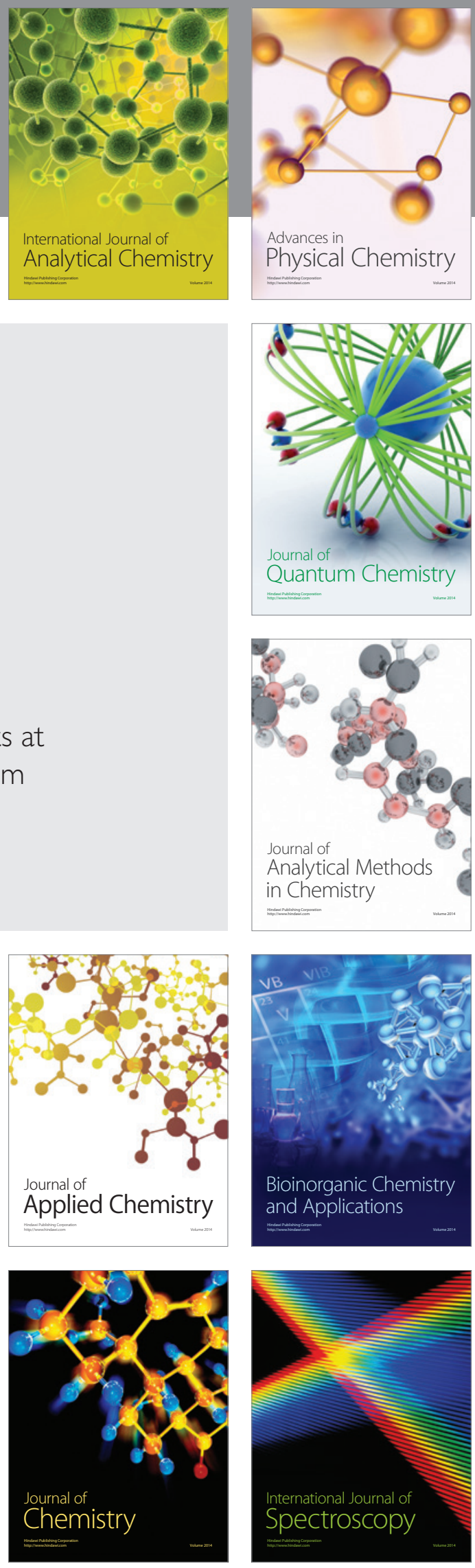